\title{
Towards Achieving a Meaningful Balance Between Work and Private Life: Insights from Argentine Workers
}

\author{
Gisela Delfino $1,2 \square$ \\ Email gisela_delfino@uca.edu.ar \\ Camila Botero 1
}

1 Pontifical Catholic University of Argentina (UCA), National Scientific and Technical Research Council (CONICET), Buenos Aires, Argentina

\begin{abstract}
The abstract is published online only. If you did not include a short abstract for the online version when you submitted the manuscript, the first paragraph or the first 10 lines of the chapter will be displayed here. If possible, please provide us with an informative abstract.
\end{abstract}

For more than three decades, researchers have pointed out the importance of work in adult life and its relationship with other aspects of life. It has been argued that making work a number one priority over other aspects of life can be detrimental to physical, mental, and social health. In regions, such as Argentina, where unemployment is high and there are still differences and preferences in the job opportunities that men and women have, it is important to analyse work-life balance based on gender. We revise the literature that analyses how employees are able to achieve meaningful balance between their work and private lives and examine if women could achieve the same level of balance as men.

\section{Introduction}

Current changes in the world of work are conditioned by economic and social situation. Data from Argentina social context reflects increased sociooccupational segmentation, with a high association between predominant labour scenario and poverty. This impacts on quality of life and households' conditions (Donza, 2019). In other words, there is a highly fragmented market that produces deprivation for many workers and, consequently, affects households and families and refleets in-living conditions of family groups. 
Another aggravated aspect in Argentina is the quality of employment. Labour informality is a recurrent aspect of job insecurity and represents the main job quality deficit in Argentina (Bertranou et al., 2014). "Latin America, and Argentina in particular, has been characterized throughout history by macroeconomic instability and its negative effects, both static and dynamic, on the labour market (on the level of employment, real wages, labour informality, among others)" (Bertranou \& Casanova, 2015, p. 12). Therefore, the macroeconomic environment and growth strategies become a basic fundamental aspect to generate quality employment.

It is also important to address the new ways of structuring and organizing companies, which bring with itthem new changes, for example, the introduction of new technologies. The International Labour Organization has expressed that technological transformations society is currently going through foreeforcing its way to reviewing skills and labour competences, making it possible to include what is expected in the near future. Therefore, in developing countries, like Argentina, it is essential to think aboutnew and better techno-productive systems since current processes of industrialization and modernization of the productive structure are insufficient and unfinished (Ernst \& Robert, 2019).

Economic and social changes pose new challenges for workers' protection: for example, part-time employment and therefore reduced working hours; increased number of self-employed workers; increased number of subcontractors and officials with temporary contracts; increased work and service contracts and temporary employment; new forms of employment in the information and communication sectors (teleworking, virtual companies on the Internet, etc.); greater alternation between employed and self-employed jobs (Bullinger, 2000). In Argentina, between 2018 and 2019, there was a drop in salaried workers and an increase in self-employed workers (Indec, 2019).

Considering the labour situation in Argentina, new responses to it have arisen. Global fragmentation of value chains, the interconnection of productive capacities, and the blurring of the boundaries beenomong producers, sellers, and consumers are other outstanding characteristics (Fisher \& Fuchs, 2015). In Latin America, there is growing concern regarding new forms of work and the impact that new technologies wouldwill have on employment, its characteristics, and the uncertainty about the resulting labour relations. If regulations do not consider new work forms, job insecurity will grow. Training and organization alternatives are required to guarantee workers' protection from the mismatch between existing labour policies and regulations and new forms of employment (Bensusán, 2016). 
Home delivery platforms are a pioneering experience in Latin America. They have been driven by workers engaged in goods (Rappi, Glovo) and people (Uber, Cabify, among others) transporting. The precariousness of delivery workers' conditions is evident in low wages, insecurity to which they are exposed, lack of social security, and long working hours. Complaints of disagreement have already started to arise. This type of work is in a labour market limbo. It is assumed that employment protection and regulation do not apply since it is proposed as an eventual virtual job - that is, an activity that allows the distribution of personal time between studies, work, or any other activity (del Bono, 2019). A large proportion of people who dedicate themselves to this type of work have university studies and are immigrants. In this context of high vulnerability and lack of regulation, relationship between new technologies and new forms of job insecurity deepens.

How new technology affects work, well-being, and individual and organizational performance depends not only on how advanced it is. Objectives of those who introduce it, procedures used to introduce it, and how well it adapts to the existing social system in the workplace are also relevant (Blackler \& Brown, 1986; Burnes, 1989). As mentioned by Arnold and Randall (2012), it is clear that, in many countries, individuals are increasingly aware and therefore less satisfied with the imbalance that sometimes occurs between the amount of time they spend at work and the amount of time they spend outside of it. Hence, there is a new challenge for employers who want to attract the best workers; they must also ensure that their workforce is satisfied and engaged. This way, demands that workers face in daily life, ahievingtrying to achive a balance between work and non-work activities, ean be a problemhave become problematic. "Work-life integration" concept captures the dynamics of employees trying to balance a wide range of work and non-work activities (Lewis \& Cooper, 2005).

Considering some society groups, such as low-income families, work-life balance often depends on the social support network, which is frequently essential for childcare (Kossek et al., 2008). It may even happen that what is stressful is not the time spent away from the family-; Ffor some women who work outside the home, returning home is what they find most stressful (Westman et al., 2008).

Lewis and Lewis (1997) have already mentioned the importance of job flexibility in terms of flexible and informal work arrangements. It has already been studied (Burke, 2001a) that there is a negative association between work addiction and organizational values that fosters the balance between personal and work life: work-addicted people obtain higher scores in organizational values that are negative in terms of balance between personal and work life. 
Results obtained from the quarterly survey carried out by Randstad Human Resources Company (2019) show that new technologies create tensions between work and personal life, and permanent eonneetion: 59\% of Argentinesians consider that their employer expects them to be available even after working hours. Employees' perception shows, for example, that $61 \%$ do not mind having to look at work matters in their free time at a convenient time and $66 \%$ said they answer calls or e-mails immediately when they are outside of their regular working hours. About $49 \%$ of those surveyed considered their employer expects them to be available also during their vacations. According to Randstad (2019), in Argentina and Uruguay, organizations need to work more actively so that the concept of work-life balance is incorporated into the corporate culture.

\section{Importance of Work in Adult Life}

Well-being is closely related to living conditions and living standards (GarcíaViniegras \& López González, 2003). Thus, satisfaction arises when a balance is achieved between future expectations and current achievements in different areas such as work, family, health, material conditions of life, interpersonal relationships, and couple's sexual and emotional relationships (García-Viniegras, 2005). Personal satisfaction is one of the fundamental components of well-being. It interacts between the person and his/her micro- and macro-social environment involving material and social objective conditions that offer different opportunities for personal fulfilment (García-Viniegras \& González Benítez, 2000).

Researchers have pointed out the importance of work in adult life and its relationship with other aspects of life. Global satisfaction with life is necessary and is achieved when it is distributed within a set of different activities: family, work, social relationships, food, hobbies, sports, etc. Each one reaches a greater or lesser level of importance in the life of each person. Nevertheless, if the individual becomes frustrated in one or more of these facets, he/she can focus attention on one, neglecting the rest (Fernández-Montalvo \& Echeburúa, 1998).

Work concept, its social assessment, and work motivation have undergone a great change throughout history. Work activity is a fundamental aspect of mental health (Fernández-Montalvo \& Echeburúa, 1998). Nowadays, working requires great dedication of daily time. It is not only an activity aimed to makeing money; its importance transcends a person's identity. It allows inclusion into the sociocultural environment and the achievingement of economic independence (Fernández-Montalvo, 1998). Work implies that the person can carry out his/her work activity freely; that is, when working, one can deploy his/her potential and develop it in a responsible way. In order to develop work in the best possible way, 
and to contribute to personal fulfilment, abilities and personality traits must be evaluated. Each worker has his/her style, which must be detected and improved (Griffa \& Moreno, 2011).

Conditions in which a job is developed turn out to be important for the mental health of the worker. Aspects such as opportunity of control, adequacy between demands that the position requires and capabilities of the person who performs it, interpersonal relationships, and physical security intervene on psychological wellbeing (Arnold \& Randall, 2012). It is important to observe the degree of influence that a person's behaviour, in their professional field, has on their behaviour outside of it, and how external aspects influence the well-being at work (Fernández-Montalvo \& Echeburúa, 1998; Fernández-Montalvo, 2000).

Some authors have suggested that different organizations are responsible for attracting, selecting, and conserving different kinds of people (O'Reilly, 1991; Rousseau, 1995; Schneider, 1987). Those that prioritize work are attracted to companies that offer them challenges and risks and therefore a greater labour involvement compared to normal employment (Harpaz \& Snir, 2003).

It is relevant to take into account the centrality of work, as the importance that fulfils the role of work in relation to other roles in the subject's life, such as family, community activities, and leisure (Alonso García, 2004). In 1987, the Meaning of Working (MOW) International Research Team had pointed out the importance of work at a general level and of work at any time in the life of a subject. They differentiated absolute centrality, where the role of work is extremely important, from relative centrality, where other facets, such as leisure, community, and religion, are taken into account. When work's value is absolutized, work activity would hinder and be dysfunctional withto the other areas of thea person's life (Griffa \& Moreno, 2011). According to Salanova et al. (1991), it is necessary to take into account the meaning of work and the associated values according to the cultural-historical context, since in each period work is conceptualized in different ways: as a punishment, as an obligation, as a possibility of self-realization, and even as an addiction.

During work activity, working conditions and the environment, that is, the environment in which this function is carried out, favour the life and health of the worker in some way. Work allows or contributes to personal fulfilment, to the development of the personality of those who execute it, and defines a crystallized social identity in the profession or trade (Neffa, 1999). While people work, some of the physical, biological, psychic, and mental capacities of the human being are constantly updated, conditioned by the feelings of belonging or inclusion in a group, category, or profession. At the same time, within social identity, something unique is displayed in each worker with respect to the other workers, where it 
creates strong feelings of belonging, so if questioning arises, it ean be a souree of suffering (Neffa, 2015).

As Dejours (1998) mentions, work demands a subjective mobilization at mental and psychic level of the worker. It will be necessary to compensate for the failures of the work prescribed by others and to deal with the random problems and incidents found in the reality of the labour process. The centrality of work can be both a health operator, insofar as it allows the construction of a balance with other areas of life, and it can also be presented as a limitation to personal development that may eventually cause pathological and destabilizing health effects (Alonso García, 2004; MOW International Research Team, 1987). In this sense, it has been argued that making work a number one priority over other aspects of life can be detrimental to physical, mental, and social health (Fernández-Montalvo, 1998).

Another interesting aspeet to analyse at work is what being employed generates on a personal level, sinee it offers the possibility of building a sense of existenee, that is, to strive to find meaning in what is done. For this reason, being unemployed by itself, and even if the person is working but the organization does not allow him/her to build that sense, eatuses frustration (Neffa, 1999). Beyond the importanee of getting a job that provides this sense, there may be other reasons to eontinue in a job that does not meet one's expeetations. The reasons eould be, for instanee, allowing the use and improvement of knowledge and experienee, continutus training, having finaneial autonomy and not always depending on family members or social assistanee, establishing relationships, being part of a soeial spaee, work group, and building identity (Neffa, 2015). Another interesting aspect to be analysed is what being employed can generate on a personal level, offering the possibility of building a sense of existence and finding meaning in what is being done. On the other hand, frustration can arise if the worker is prevented from building that sense of existence by a given organization or employer (Neffa, 1999). In some cases that feeling of frustration can find compensation in the possibility of having access to knowledge, improvement programs, continuous training, thus obtaining financial autonomy, establishing relationships, being part of a work group and building identity. We should highlight financial autonomy as a goal of utmost importance (Neffa, 2015).

From the perspective of mental health, work has some relevant funetionsplays relevant roles: (a) it balances the level of activity and satisfies the need to be aetive, through physical and mental energy expenditure; (b) it structures daily timeroutines, distinguishing periods dedicated to work and leisure; (c) it allows exchange of social roles: satisfying social bonds and complementing family 
emotional relationships; (d) it helps develop personal identity: aceording to the oeeupation, it by grantsing social status and allows feelings identified and valued aecording to employment (Fernández-Montalvo, 2000). The degree to which a job meets these enditionsrequirements is strongly associated with job satisfaction and mental health of workers.

\section{Argentina: A Context with Structural Inequalities}

It is important to give a context to the factors that articulate work. Various international organizations such as the World Health Organization (WHO), the International Labour Organization (ILO), the Pan American Health Organization (PAHO), and numerous national associations of professionals such as doctors, jurists, sociologists, psychologists, ergonomists, and labour economists agree that not only conditioning factors should be considered-: There are alse economic and social determinants of health, such as the economic, technological, social, and political context of a country at a given time, and the labour market, its operation, the position that soeially provides employment, and the eharaeteristies of the job in a partieular establishment of a seetor or braneh of aetivity should be taken into account as well.

The United Nation Sustainable Development Goals mark a path to harmonize three basic elements: economic growth, social inclusion, and environmental protection. They are essential for the well-being of people and societies, and promote sustainable, inclusive, and equitable economic growth to create greater opportunities for all. Although this path sounds very optimistieOn the other hand, studies show that social rights in force in Argentina demonstrate structural inequalities that are a real point of concern. Fo aehieve well-being, material conditions and social integration are often needednecessary for full sustainable human development. Therefore, when analysing living conditions, a set of operations associated with sources of well-being is considered,. Thiswhieh implies access to basic services and goods, protection of economic resources for life support, and decent habitat conditions. To achieve a definition of human and social development, beyond considering the indicators of income and monetary poverty, a set of aspects that allow for economic satisfaction and material achievements by households must be considered. The definition of well-being is much more complex since it covers not only economic indicators, but also social rights that imply a criterion of justice (Bonfiglio et al., 2019).

The Argentine Social Debt Observatory (ODSA) has been monitoring, since 2004, material and subjective deficiencies that have an impact on the essential capacities for personal and social development. Regarding the labour market, taking into account the last decades, after the 2001 crisis and until 2007-2008, there was a favourable socio-labourer progress-for example, investment growth, 
increased international competitiveness due to devaluation, taking advantage of significant idle capacity and policies aimed for domestic market expansion and extending to different countries. Therefore, adding to this, labour policies regained legal importance to protect work. As of 2009, the consumption-based model reached its limits due to lack of investments; additionally, changes in the international market did not favour Argentina; eonsequently, job creation diminisheddecreased, and improvements in the labour market stagnated. SineeAs of 2016, the scenario ishas become even more negative as the adverse international context, the lack of private investment, and low public investment have continued. In addition, anti-inflationary policy has had a direct impact on the labour context. The following two years added to this sittuation the devaluation process with its recessive effects, so inflation increased, generating income and consumption capacity decrease. One of the most used alternatives to measure the well-being of a society is economic deficiencies through monetary income. This is a fundamental resource to obtain goods and services that are basic to achieve well-being (Donza, 2019).

EikeAs in other developing countries with emerging economies, salaried and registered work with social security organizations comprises less than half of the economically active population. This situation must be taken into account within the conditions and environment that a worker submits and how this affects psychically and socially since the objective of entrepreneurs is often to maximize their profit or that of the organization without taking into account the employees' well-being (Neffa, 2015).

InOn the labour scenario, a segmentation has been generated, known as the micro-informal sector, which has a typical feature that easily oscillates between periods of occupation and others of unemployment. This is reflected in the fact that the annual income decreases due to this permanent dynamic, lack of employment relationship consolidation, seniority loss, training interruption, and permanent discontinuity of contributions to the social security system. Donza (2019) shows that labour turnover has had a marked impact in this sector, with little specialization in labour, and vulnerable labour relations with greater exposure to unemployment since the cost of layoffs for the employer is minor or null.

Workers in the informal sector are approximately $49.3 \%$ of the country's economically active population (Donza, 2019). They tend to be young (aged between 18 and 34 years), and they spend, in general, their time in precarious or unstable activities, with poor working conditions, low income, lack of social protection, and limitations to exercise labour rights. According to statistics (Donza \& Salvia, 2018), 74.5\% of their income comes from their employment 
and the remaining $25.5 \%$ is shared betweenby retirement and pension income, social assistance programmes, employment plans, and other non-labour income. There is a higher percentage of women who belong to this sector; the distribution of occupations is very different according to sex. The most frequent work in women is non-professional self-employment (45.4\%) and $22.9 \%$ work as domestic workers in households. On the men side, $57.9 \%$ perform activities as non-professional self-employed. Women, compared to men, have $40 \%$ lower probability of working in full employment (Donza, 2019).

However, another point of view to take into account is not only how Argentina's situation affects its workers in the micro-informal segment, but also-those that overwork as well, regardless of socioeconomic status. It is important to consider the salary relationship, the social security system, the workers' access to education, housing, urban planning, and public services (Ramazzini, 2004). All these variables position salaried workers in a particular place of social stratification and insert itthem together with their family in social life, establishing relationships with others (Ansoleaga, 2013). Therefore, the relationship of these factors in each person will define the general conditions of life and the impact on health. In this sense, health can be seen as the result of a constant search for balance of human beings with their peers and with the environment, which depends on the resistanee and adaptationresilience capacities of the subject to risk factors (Neffa, 2015).

\section{Work-Private Life Balance}

Dedicating long hours to work has been perceived as an appropriate behaviour, and it is socially accepted. It also responds to certain values of responsibility and a vision of progress in success and power (Fernández-Montalvo \& Echeburúa, 1998). In Latin America, employees work long hours. The idea that free time is equivalent to lost time is imposed. There is an implicit idea in organizations to consider that leisure time is not taken advantage ofnegatively and, with time, the worker internalizes this culture. Countries like-Working hours in Argentina and Chile berke from 40 and 45 hours per week, that is, 1,974 hours per year. However, other Latin American countries such as Colombia, Mexico, and Costa Rica stand out for higher number of working hours, with 2,496 hours per year according to the International Labour Organization (BAE Negocios, 2019). When Argentineians are consulted about the number of hours they work, 59\% saidy they work 10 hours or more per day, $25 \%$ affirmed they work 8 hours, and finally, 16\% declare they work 9 hours (Universia Argentina, 2013).

Europe is usually taken as a reference to promote reduction of working hours. In countries such as Denmark, Norway, Holland, and Germany, workweek is between 25 to 40 hours (BAE Negocios, 2019). Nevertheless, of those who 
exceed in Argentina the typical 8-hour workday, 46\% saidy that the eatseit is due to the work volume of work while 39\% referred financial need (Universia Argentina, 2013). Latin American countries have a number of factors such as high rates of independent workers, poorly paid jobs, job insecurity, and even cultural aspects that do not contribute to carry out this change (BAE Negocios, 2019). For example, in Argentina, of those working in the micro-informal sector, $75.9 \%$ do not have retirement contributions, $51.3 \%$ do not have health coverage, $30 \%$ were unemployed at least once in the last year, and $45.1 \%$ require more hours of work (Donza, 2019).

The main aim people try to achieve when planning to balance their work and personal life is well-being. Worker's subjective well-being is a fundamental social right that when absent confines equal opportunities (Salvia et al., 2016). A contrasted measure of well-being is psychological distress. It implies a deficit of emotional and cognitive resources, little capacity to respond to daily life's demands and difficulty in social relationships. Prevalence of employees' psychological distress varies according to working sector. In private or public sector, it is around $18 \%$ while in the micro-informal sector it rises up to $23 \%$. People working in the last sector haveendure worse psychological conditions too: $24.1 \%$ have a negative approach to problems that arise, $16.6 \%$ said they feel nothing or little happy, and $14.1 \%$ have a belief of external control (Donza, 2019).

There are differences in the well-being reported by gender; women report greater psychological distress than men do. At non-professional status, $17 \%$ of women haveundergo psychological distress, while only $9.9 \%$ of men have itreports that. At working class level, the relation is $24.4 \%$ vs. $15.2 \%$, and at marginal worker level, it is $49.9 \%$ vs. $24.3 \%$. Regarding happiness, women at working class report a greater happiness deficit than men (19.9\% vs. 10.4\%) (Donza, 2019).

Mismatches between the vital trajectory and the possibility of accompanying a professional career with economic solvency generate unconformity due to the lack of adaptation between working time and family life (Neffa, 2015). When comparing local workers with people working in Argentina but born and socialized in other regions, some differences related to work happiness arise. Foreign workers highlight the importance of teamwork, organizational culture, and sustainability, while Argentineians give high relevance to work environment, distance to work and recognition more important. In this way, Argentineians take more into account factors that affect their own happiness at work, while foreigners consider more factors that impact organizational happiness (Celada et al., 2016). 
A study carried out in seven big cities of Argentina shows that almost half of Argentine workers are affected by mood and material deterioration. Millennials (Y generation) are the ones that display the highest rates of exhaustion and feeling that work is not returning the levels of satisfaction they expected to find. There is a lack of harmony between expectations and what persons receive (Observatorio de Tendencias Sociales y Empresariales, 2019). Y generation demands jobs that fit needs of workers who want to build careers and family at the same time. They want to sustain a quieter life compared to their parents (Holliday Wayne, 2009; Howe \& Strauss, 2000). When needing to decide whether to take or change a-jobs, educated new generations of Argentineians especially value company aspects such as prioritizing the emotional well-being of its employees, open and transparent communication between managers and subordinates, wellness programmes, sports and health care, professional development and training, and the balance between personal and professional life (Cuesta et al., 2009). They privilege professional projects and think about itthem as a structuring factor of life.

Career development, learning opportunities, and interest in work are central for men and women, but they do not neglect the relevance of work-private life balance (Golik, 2013). They assign more importance to flexible hours and to possibilities of continuing training, than to remuneration. Argentine youths say they are happier when work centrality is relative. For them, friends, social networks, free time, sharing experiences, and travelling are considered the same or more important than work. Therefore, they are less concerned about losing a job (Hernández \& Serravalle, 2014). This could be interpreted as if they deid not balance properly personal life with work and as if they lacked ado not have true commitment to work.

Labour flexibility tends to be presented as opposed to traditional conception of work, exemplified by Taylorism and Fordism that seek quality and excellence at the lowest possible cost, making use of the latest technologies. Labour flexibility is currently one of the work's characteristics most valued by employees: $65 \%$ state that they would like to work less hours and explain they devote a large amount of time to routine tasks (Zodziejko, 2006). As reported by Celada et al. (2016), young Argentine employees explain that work flexibility allows them to improve the balance between work and personal life and organize better their schedules to establish family and social relationships on a regular basis. They also value the fact they can make better use of their free time to perform other activities and hobbies, and some have even reported that it allows them to free themselves of the stress generated by work.

\section{Teleworking}


Flexible schedules and remote work are valued as facilitators of balance between work and personal life (Hewlett et al., 2009). It is more and more frequent to find employees teleworking or makingdoing home office and companies that are eompletelyfull home office. A classical definition explains that teleworking occurs when salaried workers perform all or part (regularly or occasionally) of their work, outside the usual place of their activity - normally from home, using information and communication technologies (ICT) (José Andrés et al., 2001). This modality allows employee to be connected and producing no matter where the individual is (Alonso-Fernández, 2003; Ballesteros et al., 2004). In this way and given people can do their work tasks at home, they may work non-working days, like weekends, or even when they are sick (Del Líbano et al., 2004). This can occur in a strongly competitive work environment, where incentives are offered for greater productivity (Quiceno \& Venaccia Apli, 2007). Teleworking somehow becomes a form of work flexibility, which in many cases can denote a labour dependency, varying according to employer's' regulations. For this reason, different European Union and Latin American countries and companies have decided to develop a regulatory framework related to health and safety when the employee carries out this work modality (Osio Havriluk, 2015).

Anderson et al. (2002) and Lapierre and Allen (2006) argue that organizations can implement policies such as time and space flexibility like home office because it makes it easier for employees to organize and assist their families. Without a doubt, teleworking can offer different benefits and can help reconciliation between work and private life. It also gives the opportunity to enterincorporate women and people with disabilities into the world of work (Osio Havriluk, 2015). In 2010, Telecom Argentina, based in Buenos Aires, decided to develop its own manual to regulate teleworking. It has had a positive impact on other service companies (Osio Havriluk, 2015). Argentina has achieved relevant results in the area of health and safety in teleworking.

Flexible schedules offered by teleworking can increase motivation levels and help achieve greaterbetter performance and productivity. Nevertheless, it can earrygenerate negative consequences if not approached properly, especially with regard to separation between work and family life. It could also influence in terms of stress and productivity if it is diffieultfailed to define working hours. Therefore, it is necessary to establish a series of agreed common standards in relation to work uninterrupted concentration, as well as privacy and data protection issues (Escalante et al., 2006). Since 2007, Argentina has had a law related to hygiene and safety at work that incorporates the recommendations given by the International Labour Organization's Manual of Good Practices in Teleworking. It promotes the use of teleworking and allows inclusion of people with disabilities and those excluded from the current Argentine labour market. It 
also encourages youth employment, better working conditions through the use of ICT, and, above all, reconciling employees' family and working life. The Superintendence of Labour Risks is the state agency in charge of controlling work risk insurers and guaranteeing that medical assistance and monetary benefits are granted in case of work-related accidents or occupational diseases. In 2012, it has speeifieddefined teleworking and developed a Manual of Good Health and Safety Practices in Teleworking (Osio Havriluk, 2015).

\section{Unemployment}

In Argentina, there rate of unemployment is a significantly high rate of tnemployment. According to Indec (2019), the aetuatrate of unemployment is $9.7 \%$, but there is also a $24.7 \%$ that are beneficiaries of assistance programmes or employment plans. beeatse they are unemployed, soThus unemployment rate rises up to $34.4 \%$. There are some differences according to gender. Women report higher unemployment rates compared to men $(12.8 \%$ vs. $7 \%)$. When considering the socio-occupational status, women's unemployment is more significant in the working class (18.8\% vs. $3.8 \%)$. This situation is reversed as professional development increases, and at professional workers' level, unemployment of women is $2.1 \%$ while that of men is $4 \%$. The possibility of working in the microinformal sector increases 13.5 times when comparing workers in households of very low socioeconomic status with those of the medium high level. In low socioeconomic level, there are less possibilities of full employment. Workers in medium low-level households are $31 \%$ less likely to be in full employment. It decreases by $65 \%$ and $84 \%$ if they have low or very low socioeconomic status, always compared to the situation of workers of homes of medium high level (Donza \& Salvia, 2018). The region where workers reside differentiates the probability of insertion in the productive structure too. People living in Buenos Aires suburbs are 1.8 times more likely to work in the informal sector than those who live in the City of Buenos Aires (Donza, 2019).

InGiven a labour market with oversupply of workers, employers intensify the use of informal recruitment channels and their discriminatory practices. Ethnographic studies show employers can use greater discretion in their recruitment and hiring practices. Being a man of 40 years old or a woman of 35 years old operates as a limitation to being able to obtain a job. Women explain that if they are married, mother of small children and around 35 years old, their chances of finding a job are very low. In other words, having those characteristics is a safe passport to unemployment (Cerruti, 2000)). Usually, there is no recognition of skills and abilities acquired over time (Neffa, 2015). As declared by individuals, experience, knowledge accumulated over the years, becomes their main handicap when looking for a job. Being unemployed at midlife can precipitate severe depression 
or psychosomatic disorders. High unemployment rates lead to an increase in poverty levels and social marginality (Beccaria \& Lopez, 1996).

Moreover, in Argentina, some people do not work because they prefer not to. Between women, the rate is $36.3 \%$ while in men it is $10.3 \%$. The biggest difference between genders is found at working class, where $47.3 \%$ of women affirmmreports it while in men it represents $13.1 \%$. This asymmetry between men and women decreases as socio-occupational level increases, and at professional working level, $11.1 \%$ of women do not work because they do not want against $4.7 \%$ of men (Donza, 2019). Dominant cultural stream determines working and generating money as man's identity trait. In this way, loss of work implies, in many cases, a crisis of the masculine identity. To reconquer spaces and achieve an imaginary compensation, men (former) heads of family appeal with wild spontaneity to physical and/or verbal violence. Frequently, regressive behaviours of sullen resentment or resurgence of attention demands are directed to the wife (Beccaria \& Lopez, 1996). Compared with the formal (14.4\%) and public sector $(10.8 \%)$, more micro-informal workers $(30 \%)$ were unemployed at least once in the last year. Additionally, if they have not completed high school, they have a $11 \%$ less chance of having full employment. Finally, $45.1 \%$ of micro-informal workers explains they would like to work more hours althoughinspite of having a full working day ( 8 or $9 \mathrm{~h})$. In the formal sector, this willingness to increase working hours is about 21\% (Donza, 2019). Exceeding 45 hours per week is considered an over-occupation. Most of the time, in the micro-informal sector, workers need to increase income. In the formal sector, generally, necessity toof finishing the task, regardless of salary, is the main motivation (Donza \& Salvia, 2018).

\section{Women and Household Work}

In Argentina, women have been incorporated into the labour field sineefor several decades. However, there are still obstacles that make their labour insertio $n$ instead of "conflicting" put "conflictive" ... conflicting (Burin, 2008). Generally, women used to be associated with domestic space. This implied that women had to give up their aspirations to compete in the economic and political sphere because it was considered a man's function. The concept of domestic work hinders the construction of individuality and self-esteem (Vega Montiel, 2007). Many times, household work is still not recognized as work. It is nonremunerated, done after "paid" work without a schedule regulation, and tasks are performed inclusive during weekends, holidays, and vacations (Arnold \& Randall, 2012). When entering the formal labour market, women's household work is not reduced. It increases the effort and obliges women to generate different strategies to avoid neglecting household chores. Since it is done privately, it tends to be seen as a woman's obligation and this leads to a clear 
inequality between genders (Vega Montiel, 2007). Sometimes this situation correlates with depression in middle-aged women that work in the formal labour market (Burin, 1993). Women who are doctors, psychologists, biologists, dentists, architects, entrepreneurs, and professors explain they tend to be overwhelmed and need to be very creative to deal with obligations: formal work and household work (Burin, 2008). Interestingly, women who consider themselves more traditional in the way they played both maternal and labour roles usually also found themselves in a "sticky floor" from which it was very difficult to separate. They encountered difficulties in being able to separate private life from public sphere, and many times this arises as a difficulty in accessing or maintaining their career development (Burin, 2008). Within the different effects, that household work has on women's lives is that it hinders their well-being. Depression is often found as a latent problem that generates feelings of dissatisfation,monotony, isolation, and dissatisfaction (Oakley, 2018).

\section{Psychosocial Disturbances at Work}

FNowadays, there are some-psychosocial disturbances that ean befall at work, and-that,-although they eannot be pereeived direetly and are-been less visible than physical pathologies, nowadays they are seldom perceived directly. more likely to oeeur (Neffa, 2015). The - Occupational psychopathology studies the psychodynamic analysis of the intrapsychic and intersubjective processes that are manifested from the encounter with work (Sivadon \& Fernandez-Zöila, 1983), trying to look at and treat the pathogenic effects of work on mental health. In other words, it studies the psychological alterations derived from work activity, studying disorders that manifest themselves from the alterations that arise directly from work: work stress, negative consequences of working hours, interpersonal conflicts at work, and work addiction (Fernández-Montalvo, 2000).

In Argentina, absence from work has been growing on the increase due to problems related to work stress, panic attacks, and depression. These are psychological problems, and it has often been difficult to demonstrate that they are related to the workplace and need to be treated as medical conditions like physical illnesses (Neffa, 1999). Even employers often consider that the duration of a sick leave granted may be exaggerated or easily obtained. According to the legislation, all workers, if registered, are entitled to a maximum of three months of sick leave, without loss of salary or indanger of dismissal for just cause. With more than five years of seniority or family charges, this figure doubles and the licence can go up to one year, during which the position and salary are retained. From a business perspective, the absence of an employee implies a high cost for the employers that statistieally a high pereentage is eoneentrated on Monday and 
It is also common to encounter strikes that are protest mechanisms against some type of negative situation, such as low wages or poor working conditions. According to the Argentina's Ministry of Labour, in 2012, 8,333,295 individual days not worked were registered, almost double than in 2011, when the amount was $4,303,615$. The public sector is where absenteeism occurs the most, which is where more sick leave is authorized too; nevertheless, absences have also increased in the private sphere (Neffa, 2015). In order to preserve health in the work environment, it is necessary to provide a means to quickly identify these risks. To be recognized by the social security system, it should be possible to verify the nature of occupational disease and the direct and essential relationship between habitual activity and the disease. However, the causal relationships of these pathologies, whose effects are diffused and deferred, are difficult to establish (Neffa, 1999). There must be a dynamic that is built collectively in a relationship with others, through communication, cooperation, exchange, recognition, and social support from peers. It is also important to get companies involved aboutin social psychic risks at work since they directly affect motivation, generating little involvement in tasks, labour and interpersonal conflicts that influence costs, generating lack of attention in employees, reducing productivity, and causing greater risk in occupational accidents (Neffa, 2015).

\section{Workaholism and Burnout}

Family, social, and labour relations will determine the degree of interference that work addiction has inmight have on the employee's life (Echeburúa \& del Corral, 1994). This negative interference is related to physical health, personal happiness, and family and social relationships. It includes routine activities that could be carried out by other people, but the employee resist to delegateion and want to havekeep control over them (Fernández-Montalvo \& Echeburúa, 1998). Initially, consequences begin to affect their health, presenting cardiovascular alterations related to stress; family relationships are impaired, with social isolation, sense of humour loss, disinterest in interpersonal relationships that do not turn out to be productive and do not involve labour issues, and non-spontaneous sexual relations (Botero \& Delfino, 2019). In terms of health, deterioration is frequent, since these people neglect personal needs such as sleeping hours, regular rest, and periodic check-ups. It is also common to come across a wide variety of physical problems such as obesity, smoking, hypertension, and even aeeompany these problems with a-psychoactive addiction such as excessive smoking and alcohol consumption, which turns out to be very frequent (Fernández-Montalvo \& Echeburúa, 1998). Álvarez (2011) adds to this list the generation of bone-muscle problems, dermatitis, headaches, dental problems, low back pain, among others. 
Many organizations have become used to continuing the norm to eontinue working once the workday has been completed. It is even considered as a trait of success to dedicate as much time as possible to work, not taking the lunch break, or not having time for leisure or social life. Holidays and free time are achieved only at the retirement stage. As a rule, they are not only required to work as much time as possible, but they even demanded of 24 hours availability, 24 has well. Those who meet these expectations are considered outstanding employees (Castañeda Aguilera, 2010; Moreno et al., 2005). In both large and small companies, there is a phenomenon of social contagion, in which the labour involvement implicated in the excess of daily work hours is transmitted from employees who fulfil a greater hierarchical function or company managers to employees. Therefore, work addiction can also be due to not only to a personal orientation with respect to such activity but is it can be the result of a social interaction with others, as well (Moreno et al., 2005). In other cases, people who overwork, but they are-became happy shifters, they and enjoy working long hours (Novoa, 2011).

A study carried out by a recognized employment exehangeagency in Argentina reveals that $46 \%$ of Argentineians perceive themselves as having characteristics associated with work addiction, and 35\% have reported that overwork has caused them health problems such as stress (18\%), back, shoulder and neck pain (16\%), headache $(15 \%)$, gastric problems $(12 \%)$, sleeping problems $(11 \%)$, and depression (10\%) (Adecco, 2019). In fact, working more than twelve hours a day increases the probability of suffering a disease by $37 \%$. Only 3 out of 10 Argentineians, especially in the hierarchical positions, manage to take distance from their job responsibilities (Universia Argentina, 2013). Work recess is not synonymous of abandoning their tasks. However, when executives are consulted if given holidays by law are sufficient, $47 \%$ say they are not enough. On the same page, $35 \%$ say they keep an eye on the cell phone and e-mail just in case any labour issue shows up, and $32 \%$ claim to be available only for an emergency. Similarly, $24 \%$ of executives consider themselves indispensableessential and believe that their absence will negatively affect the operation of the company (Adecco, 2019). A great challenge for companies' top managers is to be able to reach balance between professional and personal life, to carry out activities that allow rest, distraction, and forgettingescape from work for a few hours, sinee this greatly improvesthus improving performance and health as well (Jaén, 2016). AQ2

Two possibilitiesrealities may affect workaholism. On the-one hand, the organizational culture often encourages this type of behaviour because budget control causes some employees to accomplish the function of two working 
positions or more. On the other hand, the danger of unemployment tustally frightens more than one, who-makes people cling to their work and make it a fundamental aspect of their lives (Castañeda Aguilera, 2010). Burke (2001b) explains that people on higher organizational levels and those workers with less seniority tend to work more overtimelonger hours and those workers with less seniority on eurrent job positions work more overtime per week eompared to those who have more seniority in similar positions. Similarly, companies struggle to continue in a highly competitive market and need workers who are ready to work longer hours tooean also devote a great deal of time to it. Therefore, the profiles they usually look for include a high level of work commitment, responsibility, great dedication, thatus promotesing abehaviour of workaholism. Because of this, there has been an mark increase in people suffering from work addiction (Del Líbano et al., 2004),, even with the opportunity to stop working (Đel Líbano et al., 2004). According to ODSA data (Donza, 2019), in Argentina, there has been an increase efin work exhaustion between 2018 and 2019. The highest levels of burnout are found in individuals with low educational level and low income. Almost $10 \%$ of these workers haveshow high values of both cynicism and exhaustion. Women are more likely to experience burnout than men (13\% vs. $7 \%)$. This may be due to women's difficulty of women torecovering emotionally after work because, in general, they continue to perform work tasks after hours. This is particularly interesting since although women are part of the labour market, they are also the main caretakers at home.

\section{Conclusion}

According to last data, in Argentina, half of employees work at the microinformal sector. They haveundergo high difficulty to-accessing to basic services, such as good porracademic training, and little insertion of women in the workforee. In this seetor, Most women tend to be only become just housewives due to their low porcentaje of insertion in the workforce. Thus and-most of them time-depend on state subsidies. Given the economic situation, the country is going through, balancing work and private life is an important challenge of utmost importance. A taek of balanee between private life and work tends to be assoeiated with people that have job and family obligations with little ehildren. However, almost half of Argentine workers are affected by mood and emotional disorders, and this is not always directly associated with salary. Argentine employees are dissatisfied with work; they feel overwhelmed and havereceive low salaryies. These affeet espeeially youthYouths are especially affected. On the positive side, educated new generation employee are not only satisfied enly-with getting a good salary;; they value private life-work balance as well. 
It is difficult to achieve balance, particularly for the lower socioeconomic level citizen, in a high unemployment context. Young people are the most damaged. The challenge then is then to improve work possibilities and give greater insertion to youth, balaneing traditional vision of work with new forms of work or benefits.be able to achieve significantly better working conditions, increasing youth insertion and balancing traditional forms of work. Work organisation methods should be able to provide more effectively this needs of both business and the workers, thus also helping significantly to increase new forms of mobility.

\section{References}

Adecco. (29/01/2019). Sólo 3 de cada 10 ejecutivos logran desconectarse durante sus vacaciones [Only 3 out of 10 executives manage to disconnect during their vacations]. https://www.adecco.com.ar/noticias/solo-3-de-cada-10-ejecutivos-logr an-desconectarse-durante-sus-vacaciones/.

Alonso García, M. A. (2004). Centralidad del trabajo y metas en el trabajo: dos variables claves en orientación laboral [Centrality of work and goals at work: two key variables in employment guidance]. Revista de Educación, 335, 319-344.

Alonso-Fernández, F. (2003). Las nuevas adicciones [New addictions]. Madrid: TEA.

Álvarez, R. (2011). Adicción al trabajo como riesgo psicosocial [Workaholic addiction as psychosocial risk]. Éxito Empresarial, 162, 1-3.

Anderson, S. E., Coffey, B. S., \& Byerly, R. T. (2002). Formal organizational initiatives and informal workplace practices: Links to work-family conflict and job-related outcomes. Journal of Management, 28(6), 787-810.

Ansoleaga, M. E. (2013). Sintomatología depresiva y consumo riesgoso de alcohol en trabajadores expuestos a factores psicosociales laborales adversos: un asunto pendiente en salud pública [Depressive symptomatology and risky alcohol consumption in workers exposed to adverse labor psychosocial factors: A pending issue in public health]. PhD thesis. Santiago de Chile: Universidad de Chile.

Arnold, J., \& Randall, R. (2012). Psicología del trabajo: comportamiento humano en el ámbito laboral [Work psychology: human behavior in the workplace]. Mexico: Pearson Educación. 
BAE Negocios (11/09/2019). Workaholics: Cuáles son los países en donde más se trabaja [Workaholics: What are the countries where you work most]. BAE Negocios. https://www.baenegocios.com/edicion-impresa/Workaholics-Cuales-so n-los-paises-en-donde-mas-se-trabaja-20190910-0062.html.

Ballesteros, A., Mestre, H., Pechobierto, N., Puigdoménech, A., \& Ramos, M. (2004). Influencia de las variables de personalidad en la adicción al trabajo en un estudio con profesores universitarios [Influence of personality variables in work addiction in a study with university professors]. Fórum de Recerca, 9, 1-11.

Beccaria, L., \& López, N. (1996). Sin trabajo. Las características del desempleo y sus efectos en la sociedad argentina [Jobless. The characteristics of unemployment and its effects on Argentine society]. Buenos Aires: UNICEF/Losada.

Bensusán, G. (2016). Nuevas tendencias en el empleo: retos y opciones para las regulaciones y políticas del mercado de trabajo [New trends in employment: challenges and options for labor market regulations and policies]. Santiago de Chile: Comisión Económica para América Latina y el Caribe (CEPAL).

Bertranou, F., \& Casanova, L. (2015). Las instituciones laborales y el desempeño del mercado de trabajo en Argentina [Labor institutions and the performance of the labor market in Argentina]. Buenos Aires: International Labour Organization.

Bertranou, F., Casanova, L., Jiménez, M., \& Jiménez, M. (2014). Empleo, calidad del empleo y segmentación laboral en Argentina [Empleo, calidad del empleo y segmentación laboral en Argentina]. Revista de Economía Laboral, 11, 24-64.

Blackler, F., \& Brown, C. (1986). Alternative models to guide the design and introduction of the new information technologies into work organizations.

Journal of Occupational Psychology, 59(4), 287-313. https://doi.org/10.1111/j.20 44-8325.1986.tb00231.x.

Bonfiglio, J. I., Vera, J., \& Salvia, A. (2019). Pobreza monetaria y vulnerabilidad de derechos. Inequidades de las condiciones materiales de vida en los hogares de la argentina urbana (2010-2018) [Monetary poverty and vulnerability of rights. Inequities of material living conditions in the homes of urban Argentina (20102018)]. Buenos Aires, Argentina: Educa.

Botero, C., \& Delfino, G. (2019). Adicciones al trabajo: factores psicológicos predisponentes, consecuencias de la adicción y tratamientos psicológicos [Work 
addictions: predisposing psychological factors, consequences of addiction and psychological treatments]. Hologramática, 30(1), 69-87.

Bullinger, H. (2000). The changing world of work: prospects and challenges for health and safety. Magazine of the European Agency for Safety and Health at Work, 2, 8-13.

Burin, M. (1993). Mujeres y salud mental: un estudio acerca de los estados depresivos en mujeres de mediana edad [Women and mental health: a study about depressive states in middle-aged women]. $\mathrm{PhD}$ thesis, Universidad de Belgrano, Buenos Aires.

Burin, M. (2008). Las "fronteras de cristal" en la carrera laboral de las mujeres. Género, subjetividad y globalización [The "glass frontiers" in the women's career. Gender, subjectivity and globalization]. Anuario de psicologia/The UB Journal of Psychology, 39(1), 75-86.

Burke, R. J. (2001a). Workaholism in organizations: The role of organizational values. Personnel Review, 30(6), 637-645. https://doi.org/10.1108/EUM00000000 05977.

Burke, R. J. (2001b). Predictors of workaholism components and behaviors. International Journal of Stress Management, 8(2), 113-127.

Burnes, B. (1989). New technology in context: The selection, introduction, and use of computer numerically controlled machine tools. Aldershot: Avebury.

Castañeda Aguilera, E. (2010). Adicción al trabajo (Workaholism). Patología psicosocial del siglo XXI [Workaholism. Psychosocial pathology of the 21st century]. Salud de los Trabajadores, 18(1), 57-66.

Celada, S., Gomes, F., \& Varela, J. (2016). Felicidad en el trabajo [Happiness at work]. Bachelors thesis. Universidad Argentina de la Empresa, Buenos Aires.

Cerrutti, M. (2000). Intermittent employment among married women: A comparative study of Buenos Aires and Mexico City. Journal of Comparative Family Studies, 31(1), 19-43.

Cuesta, E. M., Ibáñez, M. E., Tagliabue, R., \& Zangaro, M. (2009). La nueva generación y el trabajo [The new generation and work]. Barbarói, 2(31), 126138. 
Dejours, C. (1998). Souffrance en France: La banalisation de l'injustice sociale [El sufrimiento en Francia: la trivialización de la injusticia social]. París: Seuil.

Del Bono, A. (2019). Trabajadores de plataformas digitales: condiciones laborales en plataformas de reparto a domicilio en Argentina [Workers of digital platforms: Working conditions in on-demand delivery platforms in Argentina]. Cuestiones de Sociología, 20, 083. https://doi.org/10.24215/23468904e083.

Del Líbano, M., García, M., Llorens, S., \& Salanova, M. (2004). ¿Existen relaciones significativas entre adicción al trabajo y satisfacción? Fórum de Recerca, 9, 1-9.

Donza, E., \& Salvia, A. (2018). Características de los trabajadores del sector micro-informal y efectos sobre el desarrollo humano: 2010-2017 [Characteristics of workers in the micro-informal sector and effects on human development: 2010-2017]. Buenos Aires: Observatorio de la Deuda Social Argentina, Universidad Católica Argentina.

Donza, E. (2019). Heterogeneidad y fragmentación del mercado de trabajo (2010-2018) [Heterogeneity and fragmentation of the labor market (20102018)]. Buenos Aires: Educa.

Echeburúa, E., \& del Corral, P. (1994). Adicciones psicológicas: Más allá de la metáfora [Psychological addictions: Beyond the metaphor]. Clínica Y Salud, 5(3), 251-258.

Ernst, C., \& Robert, V. (2019). Cambio tecnológico y futuro del trabajo. Competencias laborales y habilidades colectivas para una nueva matriz productiva en Argentina [Technological change and future of work. Labor competencies and collective skills for a new productive matrix in Argentina]. Buenos Aires: International Labour Organization.

Escalante, Z., Cendrós, J., \& Urdaneta, E. (2006). El teletrabajo y sus implicaciones legales en el estado Zulia [Teleworking and its legal implications in Zulia state]. Revista Gaceta Laboral, 12(2), 232-266.

Fernández-Montalvo, J. (1998). Los trastornos psicológicos derivados del trabajo: Hacia una psicopatología laboral [Psychological disorders arising from work: towards an occupational psychopathology]. Clínica Y Salud, 9(3), 607-620.

Fernández-Montalvo, J. (2000). La psicopatología laboral: una disciplina olvidada en las relaciones entre la salud y el trabajo [Occupational 
psychopathology: A forgotten discipline in the relationships between health and work]. Huarte de San Juan. Psicología Y Pedagogía, 6-7, 127-142.

Fernández-Montalvo, J., \& Echeburúa, E. (1998). Laborodependencia: Cuando el trabajo se convierte en adicción [Labor dependency: When work becomes addiction]. Revista de Psicopatología Y Psicología Clínica, 3(2), 103-120.

Fisher, E., \& Fuchs, C. (2015). Reconsidering value and labour in the digital age. Hampshire, UK: Palgrave Macmillan.

García-Viniegras, C. (2005). El bienestar psicológico: dimensión subjetiva de la calidad de vida [Psychological well-being: subjective dimension of quality of life]. Revista Electrónica de Psicología Iztacala, 8(2), 1-20.

García-Viniegras, C., \& González Benítez, I. (2000). La categoría bienestar psicológico: Su relación con otras categorías sociales [The psychological wellbeing category: Its relationship with other social categories]. Revista Cubana de Medicina General Integral, 16(6), 586-592.

García-Viniegras, C., \& López González, V. (2003). Consideraciones teóricas sobre el bienestar y la salud [Theoretical considerations on well-being and health]. Revista Habanera de Ciencias Médicas, 2(7), 1-21.

Golik, M. (2013). Las expectativas de equilibrio entre vida laboral y vida privada y las elecciones laborales de la nueva generación [The equilibrium expectations between work and private life and the new generation's labor choices].

Cuadernos de Administración, 26(46), 107-133.

Griffa, M. C. \& Moreno, J. E. (2011). Claves para una psicología del desarrollo. Adolescencia, adultez, vejez [Keys to a developmental psychology. Adolescence, adulthood, old age]. Buenos Aires: Lugar.

Harpaz, I., \& Snir, R. (2003). Workaholism: Its definition and nature. Human Relations, 56(3), 291-319.

Hernández, R. A., \& Serravalle, C. D. (2014). Felicidad en el trabajo [Happiness at work]. Bachelor thesis. Universidad Argentina de la Empresa, Buenos Aires.

Hewlett, S. A., Sherbin, L., \& Sumberg, K. (2009). How Gen Y and Boomers will reshape your agenda. Harvard Business Review, 87(7-8), 71-76.

Holliday Wayne, J. (2009). Does reputation matter and if so, why? The effects of 
compensation, work-family, and managing diversity efforts on millenials' job pursuit intentions. 24th Annual Conference of the Society of Industrial/Organizational Psychology. New Orleans.

Howe, N., \& Strauss, W. (2000). Millennials rising: the next great generations. New York: Vintage.

Indec [Instituto Nacional de Estadística y Censos] (2019). Mercado de trabajo. Tasas e indicadores socioeconómicos (EPH). Tercer trimestre de 2019 [Work market. Rates and socioeconomic indicators (PHS). Third quarter of 2019]. Buenos Aires: Ministerio de Economía, Prisidencia de la Nación.

Jaén, C. (13/11/2016). Trabajo, trabajo, trabajo,...obligación vs adicción [Work, work, work, ... obligation vs. addiction]. Grandes Pymes, https://www.grandespy mes.com.ar/2016/11/13/trabajo-trabajo-trabajoobligacion-vs-adiccion/.

José Andrés, J., Olano Ocáriz, M., \& Lete Murugarren, A. (2001). Perspectiva internacional del trabajo: Nuevas formas de trabajo en la sociedad de la información [International work perspective: New ways of working in the information society]. Madrid: Ministerio de Trabajo e Inmigración.

Kossek, E. E., Pichler, S. M., Meece, D., \& Barratt, M. E. (2008). Family, friend, and neighbour child care providers and maternal well-being in low-income systems: An ecological social perspective. Journal of Occupational and Organizational Psychology, 81(3), 369-391. https://doi.org/10.1348/096317908X 324387.

Lapierre, L. M., \& Allen, T. D. (2006). Work-supportive family, familysupportive supervision, use of organizational benefits, and problem-focused coping: implications for work-family conflict and employee well-being. Journal of Occupational Health Psychology, 11(2), 169-181.

Lewis, S., \& Cooper, C. (2005). Work-life integration: Case studies of organisational change. Cornwall: Wiley.

Lewis, S., \& Lewis, J. (1997). The work-family challenge: Rethinking employment. London: Sage.

Moreno, B., Gálvez, M., Garrosa, E., \& Rodríguez, R. (2005). La adicción al trabajo [Work addiction]. Revista Psicología Conductual, 13(3), 417-428.

MOW International Research Team. (1987). The meaning of working. London: 
Academic Press.

Neffa, J. C. (1999). Actividad, trabajo y empleo: Algunas reflexiones sobre un tema en debate [Activity, work and employment: Some reflections on a topic under debate]. Orientación Y Sociedad, 1, 127-162.

Neffa, J. C. (2015). Los riesgos psicosociales en el trabajo: contribución a su estudio [Psychosocial risks at work: contribution to their study]. Buenos Aires: Centro de Estudios e Investigaciones Laborales, CONICET.

Novoa, C. (08/11/2011). ¿Es feliz en su trabajo? Tal vez usted sea un "happyshifter" y todavía no lo sabe [Are you happy at your job? Maybe you are a "happyshifter" and you still don't know]. https://www.iprofesional.com/notas/1 16972-Es-feliz-en-su-trabajo-Tal-vezusted-sea-un-happyshifter-y-todava-no-lo-sa be.

Oakley, A. (2018). The Sociology of Housework. Bristol, UK: Policy Press.

Observatorio de Tendencias Sociales y Empresariales (2019). Índice de bienestar emocional y estres laboral 2019 [Emotional well-being and work stress index 2019]. Cordoba: Universidad Siglo 21.

O'Reilly, C. A., Chatman, J., \& Caldwell, D. F. (1991). People and organizational culture: A profile comparison approach to assessing person-organization fit. Academy of Management Journal, 34(3), 487-516.

Osio Havriluk, L. (2015). Salud y seguridad en el teletrabajo. Caso: Argentina [Health and safety in teleworking. Case: Argentina]. Visión Gerencial, 2(2), 410426.

Quiceno, J., \& Vinaccia Alpi, S. (2007). La adicción al trabajo "workaholism” [Work addiction "workaholism"]. Revista Argentina de Clínica Psicológica, $16(2), 135-142$.

Ramazzini, B. (2004). Disertación acerca de las enfermedades de los trabajadores [Dissertation about workers' diseases]. La Plata: Sociedad de Medicina del Trabajo de la Provincia de Buenos Aires.

Randstad (2019). Balance entre trabajo y vida personal en jaque [Balance between work and personal life in check]. https://www.randstad.com.ar/tendencia s-360/archivo/balance-entre-trabajo-y-vida-personal-en-jaque_452/. 
Rousseau, D. (1995). Psychological contracts in organizations: Understanding written and unwritten agreements. London: Sage.

Salanova, M., Osca, A., Peiró, J. M., Prieto, F., \& Sancerni, D. M. (1991).

Significado del trabajo en los jóvenes en la transición e incorporación al mercado laboral [Meaning of work in young people in the transition and incorporation into the labor market]. Revista de Psicología General Y Aplicada, 44(1), 113-125.

Salvia, A., Bonfiglio, J. I., Donza, E., Hermida, J. C., Rodríguez Espínola, S., \& Vera, J. (2016). Tiempo de Balance: Deudas sociales pendientes al final del Bicentenario. Necesidad de atender a las demandas del desarrollo con mayor equidad e inclusión social [Balance Time: Social debts pending at the end of the Bicentennial. Need to meet the demands of development with greater equity and social inclusion]. Buenos Aires: Educa.

Schneider, B. (1987). The people make the place. Personnel Psychology, 40(3), 437-453.

Sivadon, P. \& Fernandez-Zöila, A. (1983). Temps de travail, temps de vivre. Analyses pour une psychopathologie du temps [Work time, time to live. Analyzes for a psychopathology of time]. Brussels: Pierre Mardaga.

Universia Argentina. (2013). El 46\% de los argentinos se considera adicto al trabajo [46\% of Argentines consider themselves addicted to work]. https://noticia s.universia.com.ar/empleo/noticia/2013/11/20/1064599/46-argentinos-considera-a dicto-trabajo.html.

Vega Montiel, A. (2007). Por la visibilidad de las amas de casa: rompiendo la invisibilidad del trabajo doméstico [For the visibility of housewives: breaking the invisibility of domestic work]. Politica Y Cultura, 28, 181-200.

Westman, M., Etzion, D., \& Gattenio, E. (2008). International business travels and the work-family interface: A longitudinal study. Journal of Occupational and Organizational Psychology, 81(3), 459-480. https://doi.org/10.1348/096317908X 310265 .

Zodziejko, M. (2006). Análisis de los cambios en las expectativas socioculturales de la oferta laboral: La brecha entre propuestas de valor ofrecidas por las empresas y demandas por los jóvenes profesionales de la República Argentina [Analysis of the changes in the socio-cultural expectations of the labor supply: The gap between value propositions offered by companies and demands by the 
young professionals of the Argentine Republic]. Masters thesis, Universidad Torcuato di Tella, Buenos Aires. 